\title{
THE INDUCTION OF SPORULATION IN THE BACILLI BELONGING TO THE AEROGENES CAPSULATUS GROUP. ${ }^{1}$
}

\author{
By Mabel Purefoy FitzGerald, Fellow of the Rockefeller Institute.
}

From the Laboratories of the Rockefeller Instilute for Medical Research, New York.

Is a preliminary paper delivered before the Pathological Society of New York (1907) Noguchi (1907-8 ${ }^{1}$ ) brought forward the fact that sporulation could be induced in the bacilli belonging to the Aerogenes capsulatus group by the addition of certain of the carbon compounds to the culture media. Together with these conditions he also showed that alkalinity, corresponding in degree to $\mathrm{N} / 75-\mathrm{N} / 50$, was a factor exerting a fuvourable influence on the occurrence.

Previous to this, many investigators had endeavoured to overcome the persistent resistance to spore formation displayed by Bacillus aerogenes capsulatus and its allied forms in artificial culture media.

Dunham $\left(1897^{2}\right)$ was the first to succeed in obtaining spores by using coagulated blood serum as the culture medium.

Welch $\left({ }^{3}\right)$, subsequent to the publication of his original article $\left(1892^{4}\right)$, also reports the occurrence of spores on using Loeffler's blood serum.

Herter $\left(1906^{5}\right)$, working with several strains of the "capsulatus type," found that sporulation took place with difficulty, and chiefly on special media containing blood serum.

Fraenkel $\left(1893^{6}\right)$ regarded spore formation as an inconstant occurrence with Bacillus phlegmones emphysematosa, and found spores only as an exception in cultures on artificial media.

Hitschmann and Lindenthal (1899 7), working with the same bacillus, failed to find spores.

Schattenfroh and Grassberger $\left(1900^{8}\right)$, after experiencing some difficulty in inducing sporulation of their Granulo-bacillus immobilis, found that uniform results could be obtained by using 0.1 per cent. starch agar of varied degree of alkalinity, - a necessary precaution, as the optimum alkalinity for sporulation was found to vary. In an earlier paper they also mention starch bouillon as being favourable to sporulation $\left(1899^{\circ}\right)$.

Jacque $\left(1904{ }^{\circ}\right)$, working with the same bacillus, and following the starch agar method of the above investigators, did not at first succeed in obtaining spores. He shows that the indicator used in the neutralisation of the media

1 Received July 19, 1910. 
is a point of importance. When using litmus as indicator he failed to obtain spores, but when using phenol-phthalein obtained them, both immediately and regularly, provided the inoculations were made with bacilli that had been isolated for a certain length of time. He lays stress on the fact that sporulation does not occur with certainty upon starch agar unless the strains used for inoculating have been cultivated for some little time on artificial media.

The cultures obtained from a recently isolated bacillus he regards as unlikely to contain spores, owing to vigour of growth, and cites Schattenfroh and Grassberger $\left(1900^{8}\right)$ as in agreement with this observation. He also recommends the use of Stiuler's plates for obtaining spores in starch agar.

Apart from the work of Jacque, and in spite of the success achieved with the starch agar media of Schattenfroh and Grassberger, this method appears to have received but scant attention from subsequent workers in similar fields, so that the recent observations of Noguchi form a distinct advance in the knowledge of conditions requisite to the sporulation of the members of the Aerogenes capsulatus group upon artificial culture media.

With a view to the extension of some of Dr. Noguchi's observations, the following experiments were made under his direction.

As bacilli, two strains were selected that had been isolated and jnvestigated by Dr. Noguchi; both of these were known to be nonsporulating under ordinary conditions.

The strain denominated in the text and tables as "H.O." was a strain of $B$. aerogenes capsulatus isolated from human faccs, of typical form, producing gas and non-putrefactive ; and that marked " N.M." was a denaturised strain of Rauschbrand, immobile, non-pathogenic, non-putrefactive, non-sporulating, and unable to split mannite. Denaturisation had been accomplished by long cultivation upon ordinary culture media.

Bouillon cultures of these strains, that of H.O. containing amygdalin, were heated in a water bath at from $80^{\circ}$ to $90^{\circ} \mathrm{C}$. for ten minutes, and inoculations subsequently made with the spore-containing fluid in 1 per cent. glucose agar. For these and all subsequent stock cultures, tubes containing glucose agar to the height of several centinetres were used. As routine procedure previous to inoculation, these tubes were allowed to boil for ten minutes in a water bath to displace the contained air, were quickly cooled, and after inoculation were "sealed" with additional agar. Inoculations were made every one to three days, the transference, with solid media, being performed by neans of a curved platinum spade.

For the experiments, sugar-free litmus-peptone bouillon, to which the fermentation test had been applied, was used as the culture base. This was made according to standard methods, with this exception-that addition of sodium chloride was omitted unless otherwise stated in definite experiments. The bouillon contained 1 per cent. of peptone. It was rendered neutral to litrnus paper, and the desired series of degrees of normal alkalinity and acidity obtained by the addition of $\mathrm{NaOH}$ and $\mathrm{HCl}$ solutions, in the requisite proportions, to separate flasks of this stock solution, $1 / 1 \mathrm{~N}$ solutions being usually employed.

In the tables the degree of alkalinity or of acidity of the media is designated as $\mathrm{N} / 200, \mathrm{~N} / 100$, etc., signifying that to the neutral bouillon $\mathrm{NaOH}$ and $\mathrm{HCl}$ had been added in amount corresponding to that degree of normal strength.

The carbon compounds-sugars, aicohols and a glucoside-were made up as 10 per cent. solutions in distilled water and sterilised either by passage through a Berkefeld filter, or, as a greater safeguard against infection, in the 
autoclave. They were subsequently added to the media in proportion of 1 per cent. As constituents of the bouillon, they were again subjected to the heat of sterilisation processes, either of the autoclave, or of steam (Arnold's steam steriliser), for twenty minutes on three successive days. No deleterious effects were apparent.

The sterilisation process used for each set of experiments is stated in the heading of the corresponding table, together with other details mention of which was considered necessary.

The culture tubes were placed in glass jars furnished with glass or copper lids clamped and carefully sealed with melted paraffin, and cultivated under anaerobic conditions at a temperature of $37^{\circ}$ for seven to eight days.

A combination of anaerobic methods was employed, namely :-

1. Absorption of oxygen by the presence of a watery solution of pyrogallol, rendered alkaline by $\mathrm{NaOH}$, in the base of the jar. (Biichner's method.)

2. Exhaustion of the contained air by means of a suction pump.

3. Replacement by an indifferent gas, i.e. hydrogen, generated by a Kipps². apparatus, and, ultimately, cultivation in this atmosphere. As a rule, prior to being placed in the incubator, the jar was again exhausted and filled a second time with hydrogen; subsequently part of the hydrogen was withdrawn to allow for the production of gas by the bacilli.

Several films were made from each culture, and stained by two or more methods. Gram's method was employed for the examination of the bacilli ; and in the examination for spores Ziehl Neelsen's method, with 1 per cent. watery malachite green as counter-stain, and 1 per cent. methylene-blue.

The essential experiments are given in tabulated form, and the data of others constituting repetitions with one or other type of medium are included in the text. Particulars as to the colour of the various media belore and after incubation, as well as indications of the degrees of growth obtained, are given in the tables. The presence or the absence of spores is indicated respectively by the plus and the minus sign. A mark of interrogation (?) in the sporulation record of the tables denotes doubt and the finding of occasional spores in the stained film. In many of these cases a single spore only, or two or three, were found. In otbers a few were present. Such findings appeared to be insufficient evidence of sporulation having occurred in the cultures; and with the possibility of such spores having been introduced or being in some way of adventitious origin, they were marked with a query.

Throughout the course of the experiments, control inoculations were made in 1 per cent. glucose agar with material from representative tubes of each series found to contain spores, these cultures being previously treated for ten minutes in a water bath maintained at a temperature of from $80^{\circ}$ to $90^{\circ} \mathrm{C}$. Typical growth was obtained in every case.

The carbon compounds selected for the investigation included examples of the monoses ( $d$-glucose, arabinose), dioses (saccharose, maltose, lactose), polyoses (raffinose), higher polyoses (inulin), alcohols (mannite, dulcite, isodulcite), and glucosides (amygdalin).

Throughout the paper, unless otherwise stated, the spores mentioned are to be understood as having been found in the free state. Endogenous spores were only occasionally observed. 
MEDIA WITHOUT ADDITION

TABLE I.-Results obtained with Sugar-free Peptone-Litmus Bouillon and Peptone Rafinose, Isodulcite, Mannite, Dulcite, Inulin and Amygdalin,

Media of definite reactions decanted into small test tubes in quantity of 3 c.c. and tubes antoclaved. The added to each tube of the respective series in proportion of 1 per cent. Twenty-four-hour old glucose agar conditions for seven days.

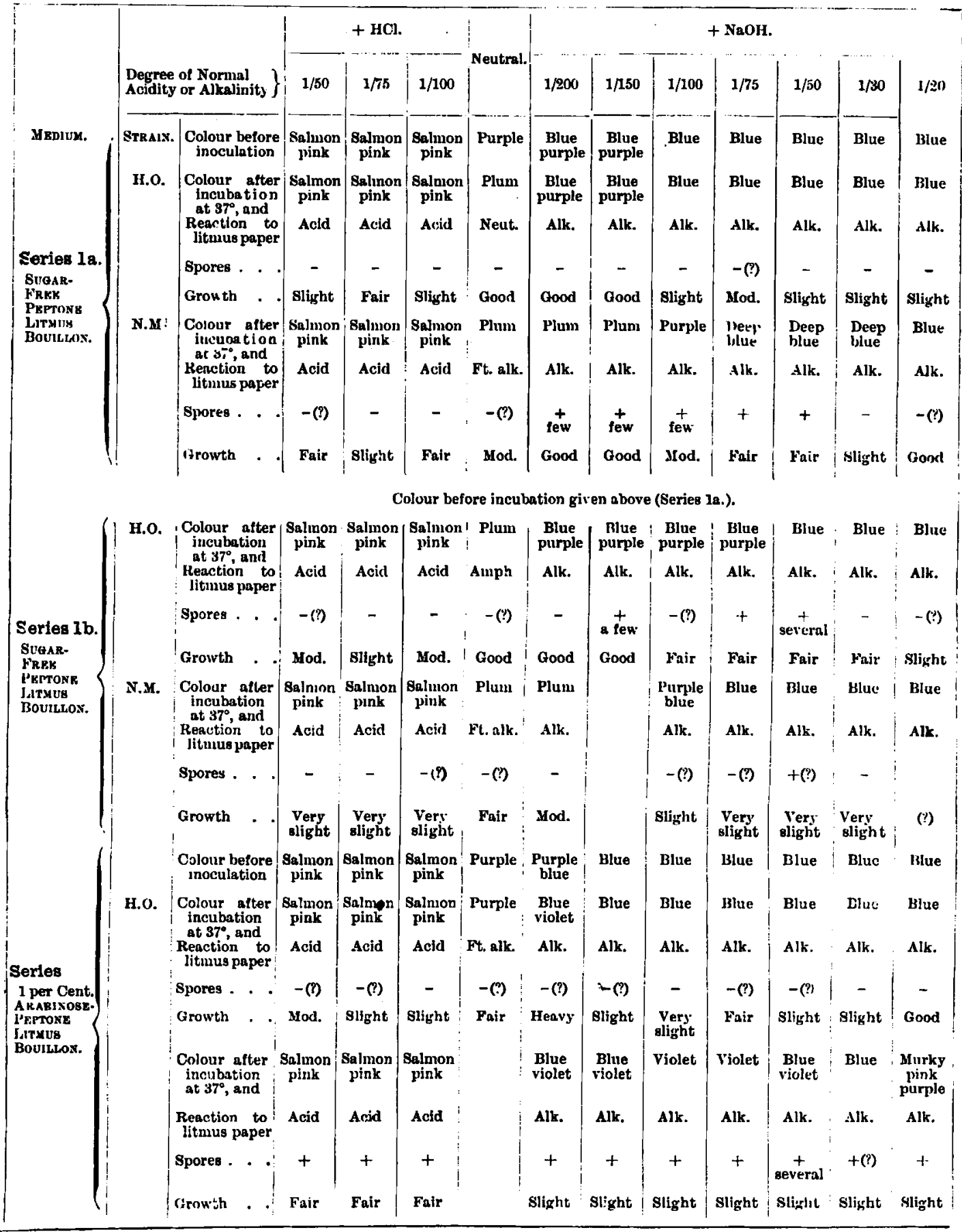




\section{OF SODIUM CHLORIDE.}

Litmus Bouillon containing respectively Arabinose, Saccharose, Maltose, Lactose, in proportion of 1 per cent. Sodium Chloride omitted.

various carbon compounds were made up in 10 per cent. solutions in distilled water and autoclaved, and then cultures emulsitied in 0.85 per cent. sterile salt solution, used for inoculations. Incubated at $37^{\circ}$ under anaerobic

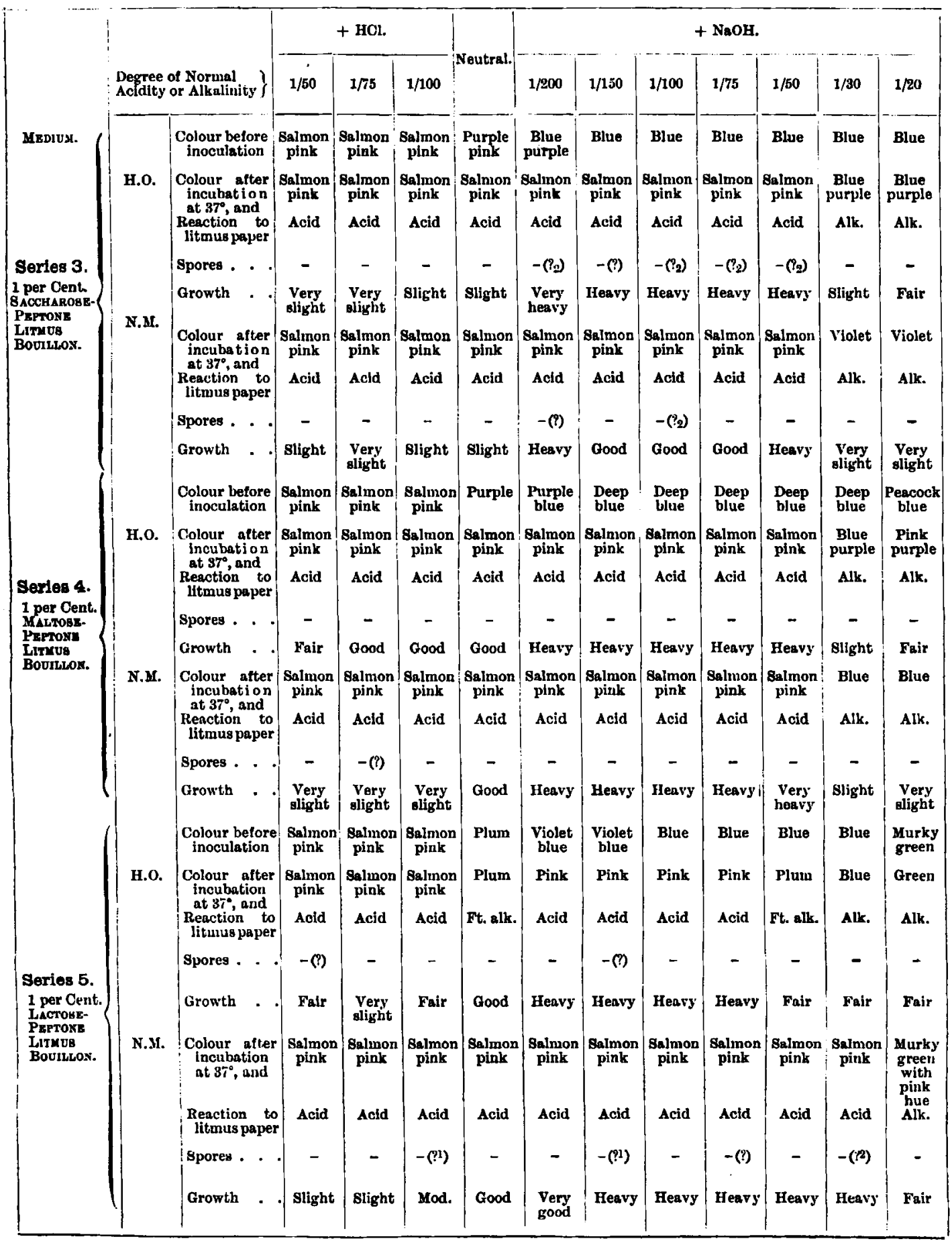


TABLR I.-continued.

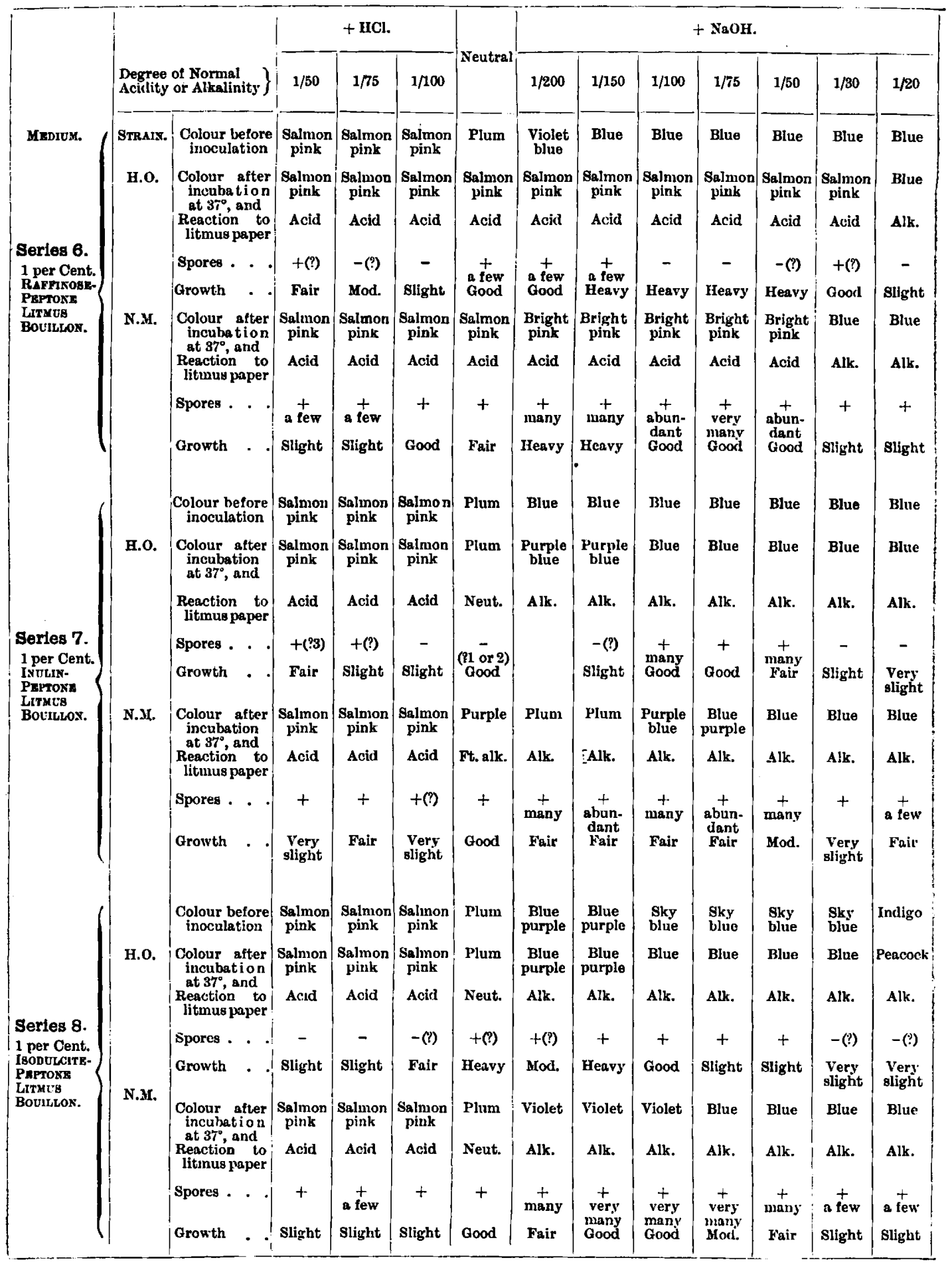




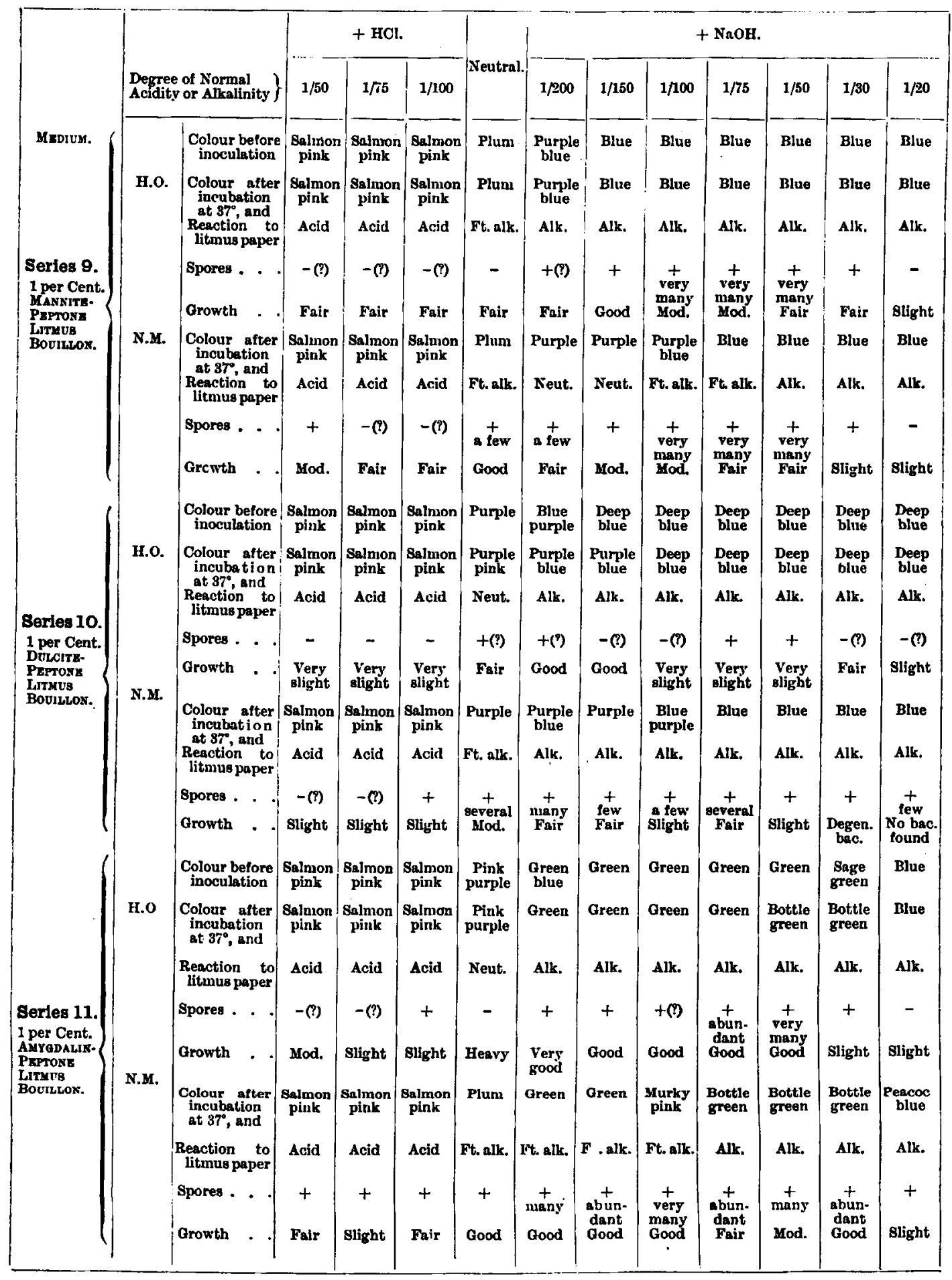




\title{
MEDIA WITHOUT ADDITION OF SODIUM CHLORIDE.
}

\author{
1. Sugar-Free Peptone Litmus Bouillon. \\ (Table I., Series 1a and 1b.)
}

In sugar-free peptone bouillon, to which no sodium chloride had been added, spore formation did not, as a rule, occur. Occasionally spores were found in the neutral media, and in alkaline media varying in degree of alkalinity from $N / 200$ to $N / 50$ occurring most frequently in $N / 75$. Solitary spores were sometimes met with in the acid media.

Neutral or alkaline media were found to be more favourable to growth than acid media, although, generally speaking, fair growth was obtained in media varying in acidity from $N / 100-N / 50$.

In the four series of experiments tabulated on page 150 (Table I., Series $1_{A}$ and 1B) no change in reaction took place during incubation. In a few instances, however (see Table III., Series 1 ), the neutral media became slightly alkaline, and acid media of very low degree, such as $\mathrm{N} / 125-\mathrm{N} / 1875$, became neutral.

Owing to the similarity of the results obtained with each strain the above remarks apply to bcth "H.O." and "N.M."

\section{MONOSES.}

\section{One Per Cent. Arabinose-Peptone Litmus Bouillon.}

\section{(Table I., Srries 2.)}

The results obtained with 1 per cent. arabinose-peptone bouillon differed with the two strains of bacilli as regards spore formation.

With strain H.O. only solitary spores were met with; it could not be said that sporulation had occurred. In the cultures of N.M. spores were present, but not abundant, throughout the acid and alkaline series, the most favourable medium being that having an alkalinity corresponding to $\mathrm{N} / 50$.

With "H.O." the extent of growth was very variable in both acid and alkaline media, but was fair in the neutral medium. In the cultures of N.M. growth was fair in the acid media, but was slight in the others.

With the exception of the neutral media becoming slightly alkaline to litmus paper, no change occurred in the reaction of the media used with either strain as the result of growth and bacillary action.

\section{One per Cent. Glucose-Peptone Litmus Boutllon.}

\section{(TABLE III., MEdium 3.)}

The effect produced by the addition of 1 per cent. $d$-glucose to the basic medium was chiefly investigated in the presence of 0.5 per cent. sodium chloride (see p. 159), and only a few tubes of alkaline media were included in the experiments in which no sodium chloride was added to the media.

The results of these experiments will be found in Table III. and on pages 164,165 . Briefly summarised to form a link in the chain of the experimental results with the monoses, they are :- 
1. Absence of spore formation in media of alkalinity corresponding in degree to $\mathrm{N} / 75, \mathrm{~N} / 50, \mathrm{~N} / 40$; and

2. Change in reaction of the media to markedly acid, provided the growth was sufficiently good.

It is thus seen that among the monoses, the pentose arabinose did not exhibit change from bacillary action, and promoted sporulation in strain N.M., while the hexose $d$-glucose readily underwent change with production of acid, and proved deterrent to the sporulation of both straine.

\section{DIOSES.}

\section{One Per Cent. Saccharose-Peptone Litmus Bouillon.}

\section{(Table I., Serieg 3.)}

The presence of 1 per cent. saccharose in the peptone bouillon did not promote sporulation. With the exception of isolated findings of solitary spores in some of the alkaline media, spores were not met with in the cultures of either strain. The modium was very favourable to growth when neutral or alkaline in degrees corresponding to $N / 200-N / 50$. With a higher degree of alkalinity, or in acid media, the growth was slight.

Marked change in reaction to acid occurred in the neutral and alkaline series up to and including the media of degree alkalinity $N / 50$. Some indication of change in colour was also observable in the alkaline media of $\mathrm{N} / 30$ and $\mathrm{N} / 20$, although the reaction was still alkaline to litmus paper.

\section{One per Cent. Maltose-Peptone Litmus Boullon.}

\section{(TABLe I., Series 4.)}

1. Entire absence of sporulation;

2. Good growth; and

3. The formation of acid to a marked degree in the originally neutral and alkaline media varying from $\mathrm{N} / 200$ to $\mathrm{N} / 50$, characterised the cultures of both strains obtained in the presence of 1 per cent. maltose.

In the originally acid series, good growth was also obtained with H.O., but slight with strain N.M. In both cases growth was slight in the media of high alkalinity. (N/30 and $N / 20)$. Some change of colour, but not of reaction, occurred in the two latter media of H.O. cultures.

\section{One per Cent. Lactose-Phptone Litmus Bouillon.}

\section{(TABLE I., Series 5.)}

Sporulation may also be said to have been absent in the media containiug 1 per cent. lactose. Solitary spores were occasionally met with.

With the growth of H.O. marked change in reaction of the media to acid occurred in the alkaline series from N/200 to N/75. Similar alteration took place with N.M. cultures in the originally neutral medium and in the alkaline series from $\mathrm{N} / 200$ to $\mathrm{N} / 30$.

Generally speaking, fair growth was obtained with both strains in the acid series, and good growth in both the originally neutral and alkaline media. With H.O. the more vigorous growth occurred in the media varying in alkalinity from $N / 200$ to $N / 75$, while with strain $N . M$. equal vigour appeared to be exhibited through as wide a range of alkalinity as $\mathrm{N} / 200-\mathrm{N} / 20$. 
It is thus seen that, when added to peptone bouillon in concentration of 1 per cent, the dioses investigated were conducive to growth, but not to sporulation, and that they readily underwent change of composition, with formation of acid, in the presence of either of the strains of bacilli used.

\section{POLYOSES.}

\section{One per Cent. Raffinose-Peptone Litmus Boullion.}

\section{(Tabla I., Series 6.)}

In the presence of this sugar, acid was produced to a marked degree by both strains of bacilli, the neutral and entire alkaline series, with the exception of $\mathrm{N} / 20$, showing change of colour from deep blue to bright salmon pink.

In spite of this, spore formation was found to have occurred to an abundant extent with strain N.M. in the originally alkaline series, particularly in $\mathrm{N} / 100, \mathrm{~N} / 75, \mathrm{~N} / 50$, as well as to less extent in the originally neutral and acid series. In the cultures of H.O. only very slight indications of sporulation were observed, such as the occurrence of one or two spores, both endogenous and free, in the neutral and alkaline media $N / 200$ and $N / 150$.

The occurrence of spores together with formed acid, as exhibited by the cultures of N.M., forms the exception to the rule otherwise found constant in these experiments, - that the presence of a sugar upon which the bacilli could act, with production of acid, was inimical to sporulation.

Schattenfroh and Grassberger (1899 ${ }^{\circ}$ ), however, found spores of the Granulo-bacillus immobilis in alkaline starch media, the starch of which had undergone fermentative changes, but they regarded free alkali as necessary to sporulation, and thought that when this had been neutralised by formed acid a normal generation was developed.

With regard to the different behaviour of the two strains it is possible that raffinose was decomposed with greater difficulty by strain N.M. than by H.O., and the media being in the first place favourable, sporulation had time to occur in the cultures of N.M. before the alkali was neutralised by the formed acid or other substances inhibitory to sporulation had been produced. Also, in many other instances strain N.M. exhibited a greater disposition to sporulate than H.O.

The originally alkaline media $\mathrm{N} / 200-\mathrm{N} / 50$ proved particularly favourable to the growth of both strains, while in media of higher alkalinity only slight growth was obtained. In the originally neutral media, good growth was exhibited by H.O., fair by N.M., and in the acid series, fair growth by H.O. and slight by N.M.

\section{HIGHER POLYOSES.}

\section{One Per Cent. Inulin-Peptone Litmus Bouillon.}

\section{(Table I., Series 7.)}

The presence of 1 per cent. inulin in the peptone bouillon proved to be an incentive to spore formation, but to a lesser degree with H.O. than with N.M.

With the exception of solitary spores, none were found in the neutral or acid series of $\mathrm{H} . \mathrm{O}$. cultures, but in the alkaline media $\mathrm{N} / 100, \mathrm{~N} / 75, \mathrm{~N} / 50$ spores were present. In these three, and in the neutral media, growth was good, but in the remaining alkaline media and in the acid media it was slight. 
With N.M. spores were present throughout the entire series of acid, neutral, and alkaline media, occurring even in the alkaline medium $N / 20$. They were particularly numerous in the alkaline media corresponding to $\mathrm{N} / 150, \mathrm{~N} / 75$, and $\mathrm{N} / 50$.

Growth was slight in the acid series, but, generally speaking, was fair to good in the neutral and alkaline media.

Apart from the neutral medium becoming faintly alkaline in N.M. eultures, no change occurred in the reaction of the media employed with either strain. With both strains some indication of change in colour was observable in the media of low-degree alkalinity.

The polyose raffinose was attacked by both strains of bacilli with marked production of acid, but was conducive to the sporulation of strain N.M.; while the more complex body inulin, termed here a higher polyose, remained virtually unattacked, and was favourable to the sporulation of both strains, especially to that of strain N.M.

\section{HEXAHYDRIC ALCOHOLS.}

\section{One Per Cent. Isodulcite-Peptone litmus Boutllon.}

\section{(Table I., Series 8.)}

The presence of 1 per cent. isodulcite in peptone bouillon exerted a favourable influence upon sporulation, whether the medium was acid, neutral, or alkaline, the effect being more pronounced with strain N.M. than with strain H.O.

With H.O. spores were not found in the acid series, but were present in the neutral and the alkaline media of low-degree alkalinity, N/150, N/100 proving to be the most favourable. With N.M., spores were present throughout the series, being few in number in the acid and neutral media, but very abundant in the alkaline media, especially in degrees alkalinity $\mathrm{N} / \mathbf{1 5 0}$, $\mathrm{N} / 100, \mathrm{~N} / 75, \mathrm{~N} / 50$.

The growth was slight with both strains in the acid series, good in neutral and alkaline media varying from N/200 to N/100 with H.O., and from $\mathrm{N} / 200$ to $\mathrm{N} / 50$ with N.M. The growth of both strains was slight in the media of higher alkalinity.

No change occurred in the reaction of the media with either strain.

\section{One per Cent. Mannite-Peptone litmus Bouillon.}

\section{(Table I., Serigs 9.)}

Mannite in proportion of 1 per cent. promoted the sporulation of both strains in peptone bouillon, and more particularly in certain of the alkaline media. Occasional spores were met with in H.O. cultures in acid media, but not in the neutral.

In N.M. cultures spores were present in small numbers in the neutral and in each of the acid media. In the alkaline series, sporulation occurred in both strains in the media varying in degree of alkalinity from N/200 to $N / 30$, but did not occur in either in degree $N / 20$. The spores were present in greatest number in media corresponding in degree of alkalinity to $N / 100$, N/75, N/50.

With both strains growth was slight in acid media, moderate to good in the neutral and the greater part of the alkaline series, but slight in the media of high alkalinity $(N / 30-N / 20)$. 
A change in reaction to slightly alkaline in the originally neutral medium and in one instance also of the alkaline media, $N / 200$ and $N / 150$, to neutral, was observed in N.M. cultures, but otherwise no change in reaction occurred.

With H.O., spore formation was greater in extent in the presence of mannite than in that of isodulcite.

\section{One per Cent. Dulcite-Peptone litmus Bouillon.}

\section{(TAble I., Skrits 10.)}

Dulcite was conducive to sporulation, but in less degree than either mannite or isodulcite. Its presence exerted greater influence upon strain N.M. than upon H.O.

With H.O., spores were found in greatest number in the alkaline media $N / 75$ and $N / 50$, and only occasional spores were met with in the other cultures. In the N.M. cultures, spore formation occurred in the neutral and in the alkaline media ranging in alkalinity from $\mathrm{N} / 200$ to $\mathrm{N} / 20$, the number of spores being greatest in $\mathrm{N} / 200$ and $\mathrm{N} / 75$.

Growth was slight in the acid series of both strains, fair in neutral or alkaline media of low-degree alkalinity, but otherwise slight. With the exception of the neutral medium of N.M. becoming faintly alkaline, no change occurred in the reaction of the media with either strain.

The hexahydric alcohols thus proved to be incentives to the sporulation of both the strains investigated. It must also be observed that, apart from slight changes occurring in one or two instances in the reaction of media containing mannite, these carbon compounds did not exhibit change of composition from bacillary action.

\section{GLUCOSIDES.}

\section{One per Cent. Amygdalin-Peytone litmus Bouillon.}

\section{(TablF, I., Srrirs 11.)}

The addition of 1 per cent. amygdalin induced the sporulation of both strains in peptone bouillon. The effect produced was considerably more marked in strain N.M. than in strain H.O.

As a rule, spores were not found either in the neutral or acid media of the H.O. cultures, but were present in the alkaline media varying in degree of alkalinity from $N / 200$ to $N / 30$, the $N / 75$ and $N / 50$ media proving the most favourable. With N.M., spores were found in the acid and neutral media, and to an abundant extent in the alkaline series, especially within the range of alkalinity $\mathrm{N} / 150-\mathrm{N} / 50$. In two of the series spores were also abundant in $\mathrm{N} / 20$.

The degree of growth obtained in the presence of amygdalin was somewhat inconstant. Generally speaking, it was good in alkaline media varying in degree from $\mathrm{N} / 200$ to $\mathrm{N} / 50$, and slight in higher degrees of alkalinity. In the acid series the extent of growth varied from very slight to fair, and in noutral media from fair to heavy.

No change occurred in the reaction of the media. In one series an indication of change in colour was observable in the alkaline media $N / 200$ and $\mathrm{N} / 75$.

The glucoside amygdalin was conducive to the sporulation of both strains, and was virtually unattacked. 


\section{MEDIA CONTAINING 0.5 PER CENT. SODIUM CHLORIDE.}

\section{TABLE II.-Results obtained woith 1 per cent. Glucose-Peptone Litmus Bouillon containing 0.5 per cent. Sodium Chloride.}

Glucose made up in 10 per cent. solution in distilled water, sterilised by passage through a Berkefeld filter, and added to stock flasks of media in proportion of 1 per cent. Stock flasks of media, containing sugar, steam sterilised for twenty minutes on three successive days, and decanted into small test-tubes. Tubes contrining media sterilised by steam prior to inoculation. Twenty-four-hour old glucose agar cultures used for inoculations, emulsified in sterile 0.85 per cent. $\mathrm{NaCl}$ solntion. Ineubated under anaerobic conditions for eight to nine days.

\begin{tabular}{|c|c|c|c|c|c|c|c|c|c|c|c|c|c|}
\hline & & & & $+\mathrm{HCl}$ & & & & & & + $\mathrm{NaOH}$ & & & \\
\hline & $\begin{array}{l}\text { Degree } \\
\text { Acidity }\end{array}$ & $\left.\begin{array}{l}\text { of Normal } \\
\text { or Alkalinity }\end{array}\right\}$ & $1 / 125$ & $1 / 187$ & $1 / 250$ & & $1 / 200$ & $1 / 150$ & $1 / 100$ & $1 / 75$ & $1 / 50$ & $1 / 40$ & $1 / 30$ \\
\hline ToniciT:. & Strals. & $\begin{array}{c}\text { Colour before } \\
\text { inoculation }\end{array}$ & $\begin{array}{c}\text { Salmon } \\
\text { pink }\end{array}$ & $\begin{array}{c}\text { Murky } \\
\text { pink }\end{array}$ & $\underset{\text { pink }}{\text { Murky }}$ & Indigo & Indigo & $\begin{array}{c}\text { Blue } \\
\text { indigo }\end{array}$ & $\begin{array}{c}\text { Blue } \\
\text { indigo }\end{array}$ & $\begin{array}{c}\text { Blue } \\
\text { indigo }\end{array}$ & Green & $\begin{array}{l}\text { Brown } \\
\text { green }\end{array}$ & $\begin{array}{l}\text { Green } \\
\text { brown }\end{array}$ \\
\hline & H.O. & $\begin{array}{c}\text { Colour after } \\
\text { incubation }\end{array}$ & $\begin{array}{l}\text { Salmon } \\
\text { pink }\end{array}$ & $\begin{array}{l}\text { Pink } \\
\text { purple }\end{array}$ & $\begin{array}{c}\text { Pink } \\
\text { purple }\end{array}$ & \begin{tabular}{|c|} 
Salmon \\
pink
\end{tabular} & $\begin{array}{l}\text { Salmon } \\
\text { pink }\end{array}$ & $\underset{\text { pink }}{\text { Balmon }}$ & $\begin{array}{l}\text { Salmon } \\
\text { pink }\end{array}$ & $\begin{array}{c}\text { Salmon } \\
\text { pink }\end{array}$ & Green & Brown & Brown \\
\hline & & $\begin{array}{l}\text { Reaction to } \\
\text { litmus paper }\end{array}$ & Acid & Acid & Acid & Acid & Acid & Acid & Acid & Acid & Alk. & Neut. & Neut. \\
\hline & & Spores. & - & - & - & - & $-(?)$ & - & - & - & - & - & - \\
\hline $\begin{array}{c}0.5 \text { per Cent. } \\
\text { NaCl. }\end{array}$ & & Growth . . & Slight & Slight & Slight & Good & Good & Very & Very & Very & Slight & Slight & Slight \\
\hline & N.MI. & Colour after & $\begin{array}{l}\text { Salnon } \\
\text { pink }\end{array}$ & $\begin{array}{r}\text { Murky } \\
\text { pink. }\end{array}$ & $\begin{array}{c}\text { Murky } \\
\text { pink }\end{array}$ & $\begin{array}{l}\text { Blue } \\
\text { purple }\end{array}$ & Indigo & Indigo & $\begin{array}{c}\text { Blue } \\
\text { jndigo }\end{array}$ & Blue & Brown & $\begin{array}{c}\text { Golden } \\
\text { brown }\end{array}$ & $\underset{\text { gold }}{\text { Old }}$ \\
\hline & & $\begin{array}{l}\text { Reaction to } \\
\text { litmus paper }\end{array}$ & Acid & Acid & Ft. alk. & Ft. alk. & Alk. & Alk. & Alk. & Ft. alk. & Ft. alk. & Ft. alk. & Ft. alk. \\
\hline & & Spores . & - & - & $-(?)$ & - & - & - & - & - & - & - & - \\
\hline & & Growth & Slight & (i) & $\begin{array}{l}\text { Very } \\
\text { slight }\end{array}$ & Fair & Fair & $\begin{array}{l}\text { Very } \\
\text { slight }\end{array}$ & $\begin{array}{l}\text { Very } \\
\text { slight }\end{array}$ & $\begin{array}{l}\text { Very } \\
\text { elight }\end{array}$ & $\begin{array}{l}\text { Very } \\
\text { slight }\end{array}$ & Fair & Slight \\
\hline
\end{tabular}

One per Cent. Glucose-Peptone Litmus Boulllon contanning 0.5 Per cent. NaCl. (Table II.)

As a complete series of 1 per cent. glucose-peptone bouillon was not included in the experiment in which sodium cbloride was omitted from the media, the results obtained with a complete series of glucose bouillon cultures containing 0.5 per cent. sodium chloride are here given.

Spore formation was not induced by the presence of this sugar. Very rarely, solitary spores were met with, but from the sum of the experiments these could not be regarded as furnishing evidence of sporulation.

The addition of glucose to the media in proportion of 1 per cent. did not appear to be persistently conducive to good growth, the extent of this being very variable in acid, neutral, or alkaline media. Generally speaking, it may be said that growth was slight in the acid media, fair to good in neutral as well as in alkaline media of low degrees of alkalinity, and slight in alkaline media $\mathbf{N} / 40, \mathbf{N} / 30$.

If sufficiently good growth occurred the originally neutral and alkaline media became markedly acid.

It is interesting to note that Selter (1904 ${ }^{11}$ ) found that the addition of glucose to bouillon in proportion of 2 per cent. furthered rather than hindered spore formation in the following anaerobes: $B$. cedematis maligni, B. anthracis symptomatici, $B$. botulinus, $B$. tetani. Sporulation of these bacilli also occurred in 2 per cent. lactose bouillon. 
MEDIA CONTAINING SODIUM

\section{TABLE III.-Results oltained with Sugar-free Peptone Litmus Bouillon, Anygdalin-Peptone Litmus}

Glucose and amygdalin made up in 10 per cent. solution in distilled water, sterilised by passage through 1 per cent. Media decanted into small test tubes in quantity of 3 c.c. and sterile NaCl solutions of and 5.0 per cent. $\mathrm{NaCl}$. 1 c.c. of sterile water added to salt-free series. Twenty-four-hour old Incubated at $37^{\circ}$ under anaerobic conditions for seven to eight days.

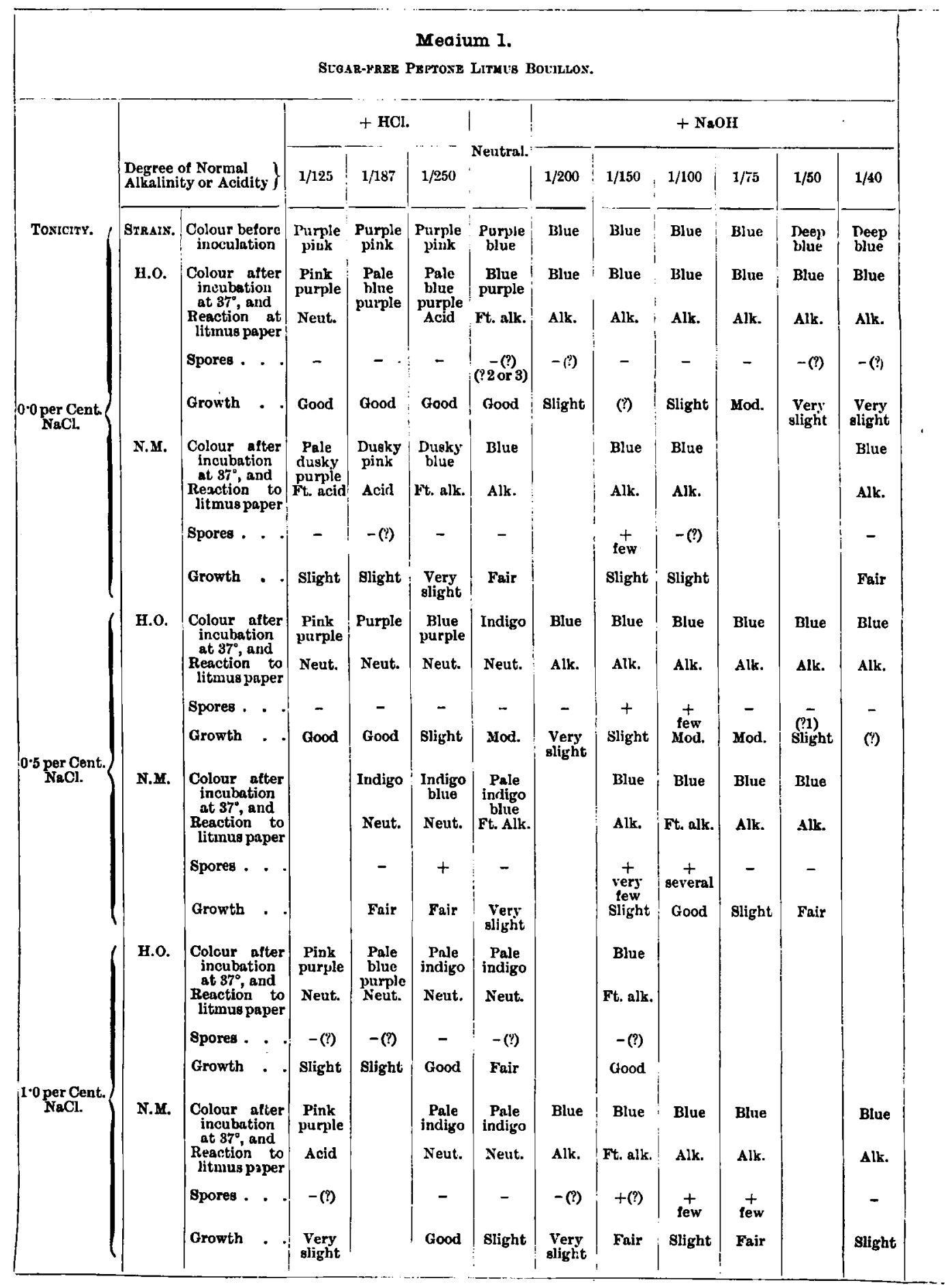




\section{CHLORIDE IN VARYING DEGREE.}

1 per cent. Glucose-Peptone Litmus Bouillon, and 1 per cent.

Bouillon of Varying Tonicity.

Berkefeld filter, and added respectively to flasks of stock bouillon of definite reactions in proportion of different concentrations added in quantity of 1 c.c., giving proportions of $0 \cdot 5,1 \cdot 0,1 \cdot 5,2 \cdot 0,3 \cdot 0$, glucose agar cultures emulsitied in sterile 0.85 per cent. $\mathrm{NaCl}$ solution used for inoculations.

\begin{tabular}{|c|c|c|c|c|c|c|c|c|c|c|}
\hline \multicolumn{8}{|c|}{$\begin{array}{l}\text { Medium } 2 . \\
1 \text { per Cext. Amyonals-Pzprona Litrus Boullox. }\end{array}$} & \multirow{2}{*}{\multicolumn{3}{|c|}{$\begin{array}{c}\begin{array}{c}\text { Medium 3. } \\
\text { 1 PER CENT. GLucooss- } \\
\text { Psproxi LirMrs BoulLLoN. }\end{array} \\
+ \text { NaOH. }\end{array}$}} \\
\hline \multicolumn{2}{|c|}{ + HCl. } & \multirow{2}{*}{ Neutral. } & \multicolumn{5}{|c|}{$+\mathrm{NaOH}$} & & & \\
\hline $1 / 125$ & $1 / 187$ & & $1 / 150$ & $1 / 100$ & $1 / 78$ & $1 / 50$ & $1 / 40$ & $1 / 75$ & $1 / 50$ & $1 / 40$ \\
\hline $\begin{array}{c}\text { Dusky } \\
\text { pink }\end{array}$ & $\begin{array}{c}\text { Dusky } \\
\text { pink }\end{array}$ & & Green & Green & $\begin{array}{c}\text { Blue } \\
\text { green }\end{array}$ & $\begin{array}{l}\text { Grass } \\
\text { green }\end{array}$ & Blue & Blue & Blue & Blue \\
\hline & & $\begin{array}{l}\text { Murky } \\
\text { green }\end{array}$ & & Green & & Green & Grean & Blue & Pink & Biue \\
\hline & & Ft. alk. & & Alk. & & Alk. & Alk. & & Acid & Alk. \\
\hline & & $\underset{\text { very }}{+}$ & & $\underset{\text { very }}{+}$ & & $\underset{\operatorname{many}}{+}$ & - & $t(? 3)$ & - & - \\
\hline & & $\begin{array}{l}\text { Mluch } \\
\text { degen. }\end{array}$ & & Frir & & Fair & $\begin{array}{l}\text { Very } \\
\text { slight }\end{array}$ & $\begin{array}{l}\text { Very } \\
\text { slight }\end{array}$ & Good & $\begin{array}{c}\text { Very } \\
\text { Blight }\end{array}$ \\
\hline & & & & & Green & Green & Green & $\begin{array}{c}\text { Salmon } \\
\text { pink }\end{array}$ & & Blue \\
\hline & & & & & Alk. & Alk. & Alk. & Acid & & Alk. \\
\hline & & & & & $\stackrel{+}{+}$ & 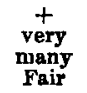 & $\begin{array}{l}+ \\
\text { very } \\
\text { many } \\
\text { Good }\end{array}$ & - & & (? growth) \\
\hline $\begin{array}{c}\text { Murky } \\
\text { pink }\end{array}$ & & & Green & Green & Green & Green & Green & Blue & Blue & Blue \\
\hline Ft. acid & & & Ft. alk. & Alk. & Ft. alk. & Alk. & Ft. alk. & Alk. & Alk. & Alk. \\
\hline 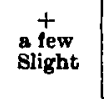 & & & $\begin{array}{c}+ \\
\text { Fair }\end{array}$ & $\underset{\text { a few }}{+}$ & $\underset{\substack{\text { few } \\
\text { Good }}}{+}$ & $\underset{\substack{\text { Sery } \\
\text { Blight }}}{-}$ & $\left(\begin{array}{l}+ \\
(?+1 \text { or } 2 \\
\text { Good }\end{array}\right.$ & $\begin{array}{c}- \\
\text { very } \\
\text { slight }\end{array}$ & $\begin{array}{l}-(?) \\
(?)\end{array}$ & $\begin{array}{c}- \\
\text { (? growth) }\end{array}$ \\
\hline & & & & Green & Green & Green & Green & $\begin{array}{c}\text { Salmon } \\
\text { pink }\end{array}$ & & Blue \\
\hline & & & & Ft. allk. & Alk. & dlk. & Alk. & Acid & & Alk. \\
\hline & & & & $\underset{\mathrm{a} \text { few }}{+}$ & (? a few) & + & $\stackrel{+}{\operatorname{man} y}$ & (?) & & - \\
\hline & & & & Fair & $\begin{array}{l}\text { Very } \\
\text { slight }\end{array}$ & $\begin{array}{c}\text { Very } \\
\text { slight }\end{array}$ & Good & Heavy & & Good \\
\hline $\begin{array}{c}\text { Mrurky } \\
\text { brownish } \\
\text { creen }\end{array}$ & & & Green & & & & & $\begin{array}{c}\text { Salmion } \\
\text { pink }\end{array}$ & $\begin{array}{c}\text { Salmon } \\
\text { pink }\end{array}$ & Blue \\
\hline Neut. & & & Alk. & & & & & Acid & Acid & Ft. alk. \\
\hline $\begin{array}{c}+ \\
\text { very } \\
\text { slight }\end{array}$ & & & $\begin{array}{c}+\underset{t}{+} \\
\text { alew } \\
\text { slight }\end{array}$ & & & & & $\begin{array}{c}- \\
\text { Heavy }\end{array}$ & $\begin{array}{c}- \\
\text { Good }\end{array}$ & $\begin{array}{c}- \\
\text { Fair }\end{array}$ \\
\hline $\begin{array}{c}\text { Murky } \\
\text { pink }\end{array}$ & & & Green & & & & Green & $\begin{array}{l}\text { Salmon } \\
\text { pink }\end{array}$ & $\begin{array}{c}\text { Salmon } \\
\text { pink }\end{array}$ & $\begin{array}{l}\text { Salmon } \\
\text { pink }\end{array}$ \\
\hline Acid & & & Alk. & & & & Alk. & $\Delta c i d$ & Acid & $\Delta$ cid \\
\hline$\stackrel{+}{+}$ & & & $\stackrel{+}{\stackrel{+}{*}}$ & & & & + & - & -() & $-(3)$ \\
\hline Good & & & Good & & & & Slight & Good & Heavy & Good \\
\hline
\end{tabular}


TABLE III.-continued.

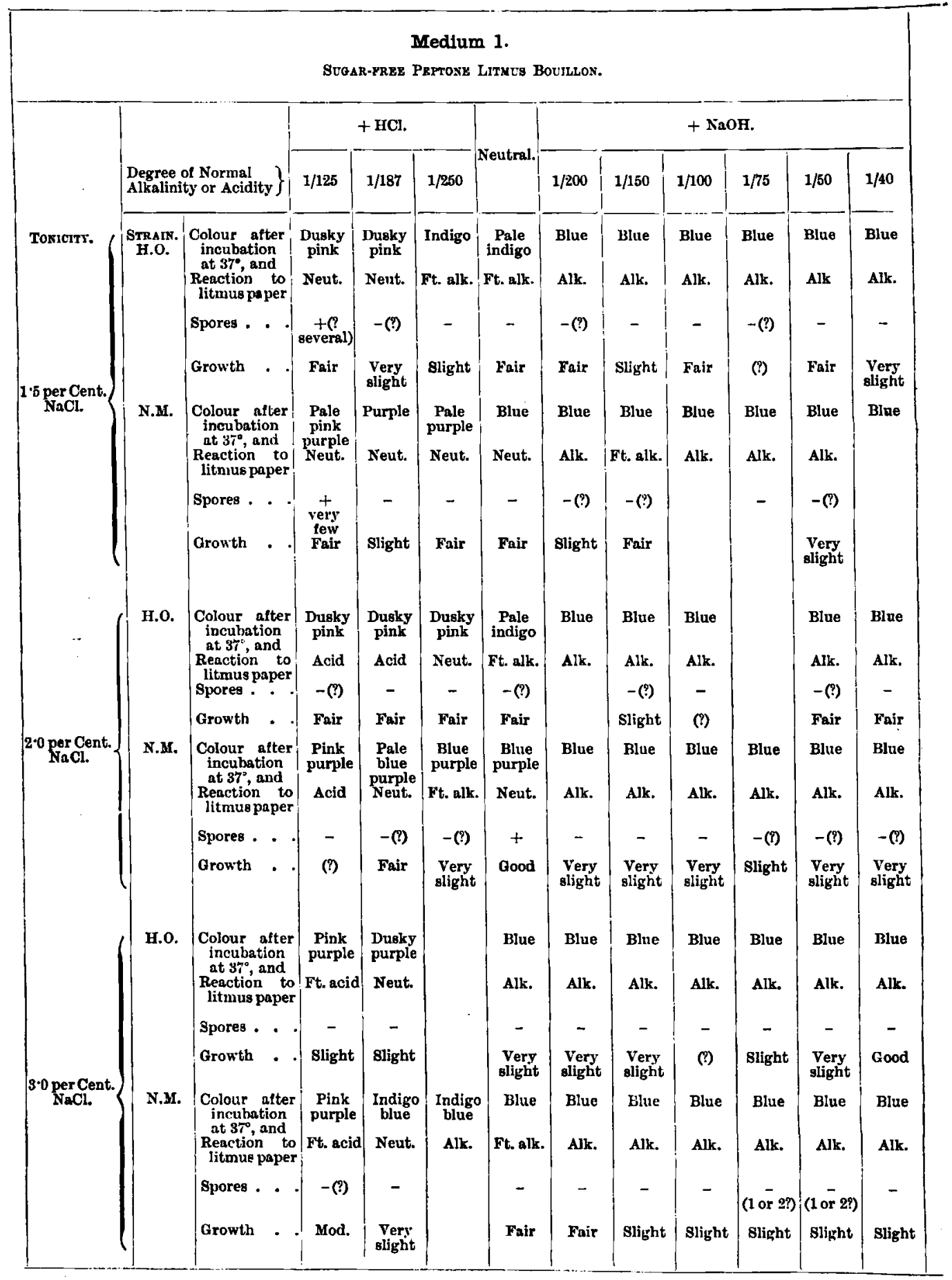




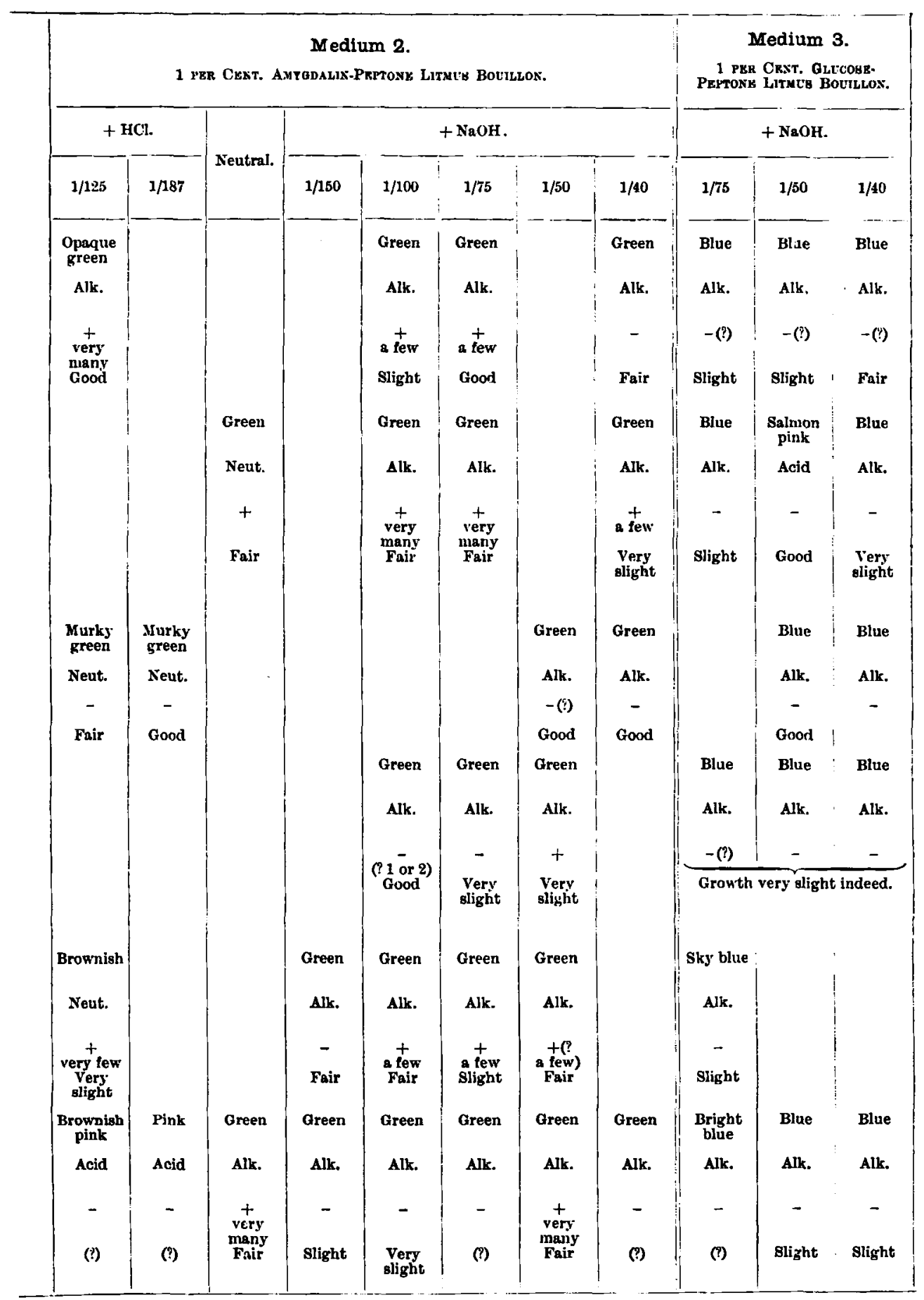


TABLE III.-continued.

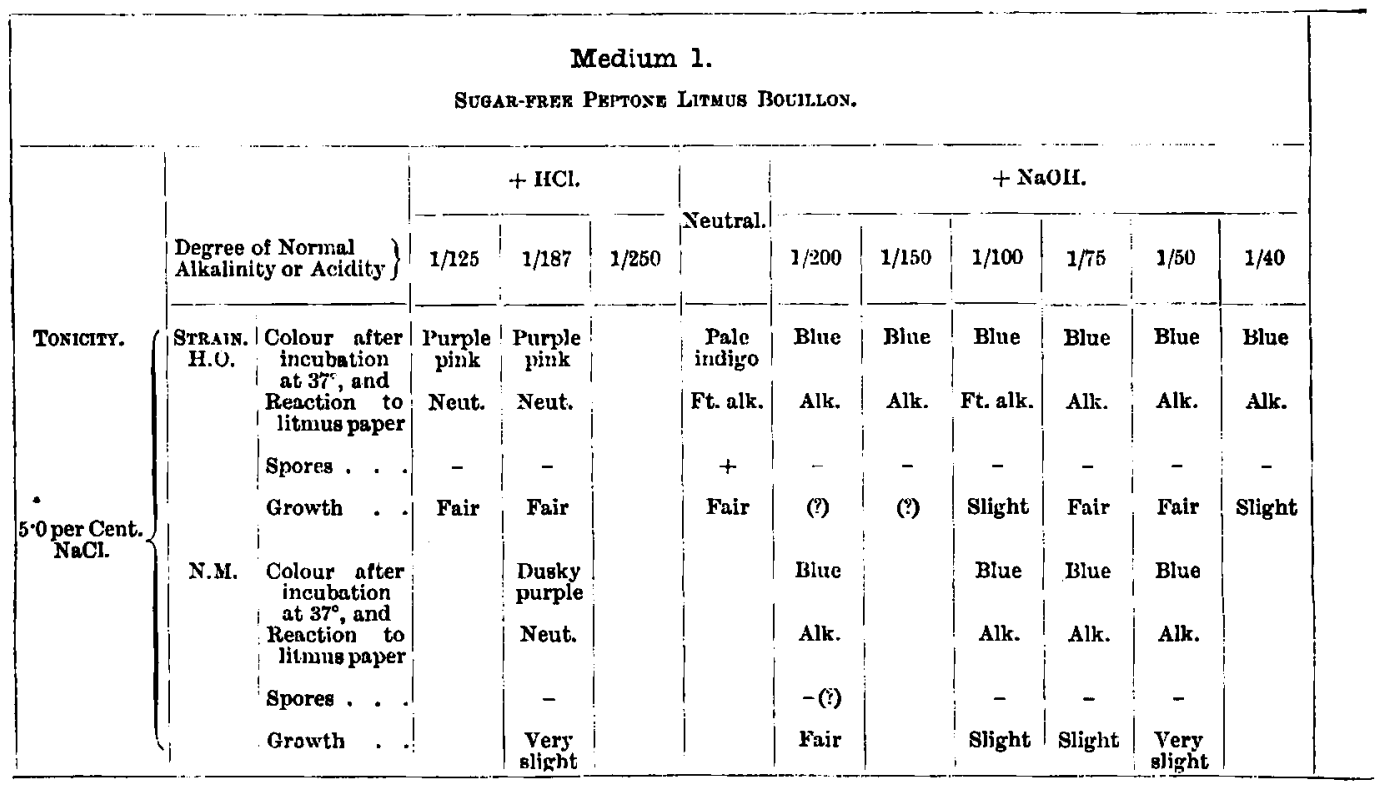

In addition to the experiments determining the primary effect of the aforenamed carbon compounds upon sporulation, some preliminary experiments were also made to ascertain whether the tonicity of the medium was a factor influencing the occurrence.

For this purpose sugar-free peptone bouillon, 1 per cent. amygdalin-peptone bouillon, and 1 per cent. glucose-peptone bouillon were chosen as media. Tubes of these media, differing in reaction, were arranged in seven series. To six of these series, sterile sodium chloride was added in definite proportion, so as to give tonicity respectively of 0.5 per cent., 1 per cent., 1.5 per cent., 2 per cent., 3 per cent., and 5 per cent. The seventh series served as control without $\mathrm{NaCl}$, and to this was added sterile water sufficient to render the quantity of fluid the same as in the other tubes.

So decided effect, due either to the presence of sodium chloride as such, or to any definite quantity of the same, could be traced in any of the series of either strain.

Spore formation was not induced in sugar-free peptone bouillon nor in 1 per cent. glucose-peptone bouillon. Occasional spores, as met with before in sugar-free bouillon, were again present in some cultures of the series containing respectively 0.5 per cent., 1 per cent., and 5 per cent. $\mathrm{NaCl}$.

In the 1 per cent. amygdalin tubes the favourable influence of the glucoside on sporulation was again brought out; but no apparent effect as regards either increase or decrease in spore formation was noticeable. Sporulation occurred as before in the absence of $\mathrm{NaCl}$, and in its presence in concentrations varying from 0.5 per cent. to 5 per cent. In these cultures, as in those examined previously, the extent of the spore formation was very variable, but sporulation occurred in acid media of low-degree acidity, in neutral, and in alkaline media. Of the latter, $\mathrm{N} / 150-\mathrm{N} / 50$ proved to be the most favourable. In the presence of 5 per cent. $\mathrm{NaCl}$, spores were present in the acid medium $\mathrm{N} / 50$, and in the alkaline medium $\mathrm{N} / 100$.

With regard to growth, in sugar-free bouillon this was found to be as 


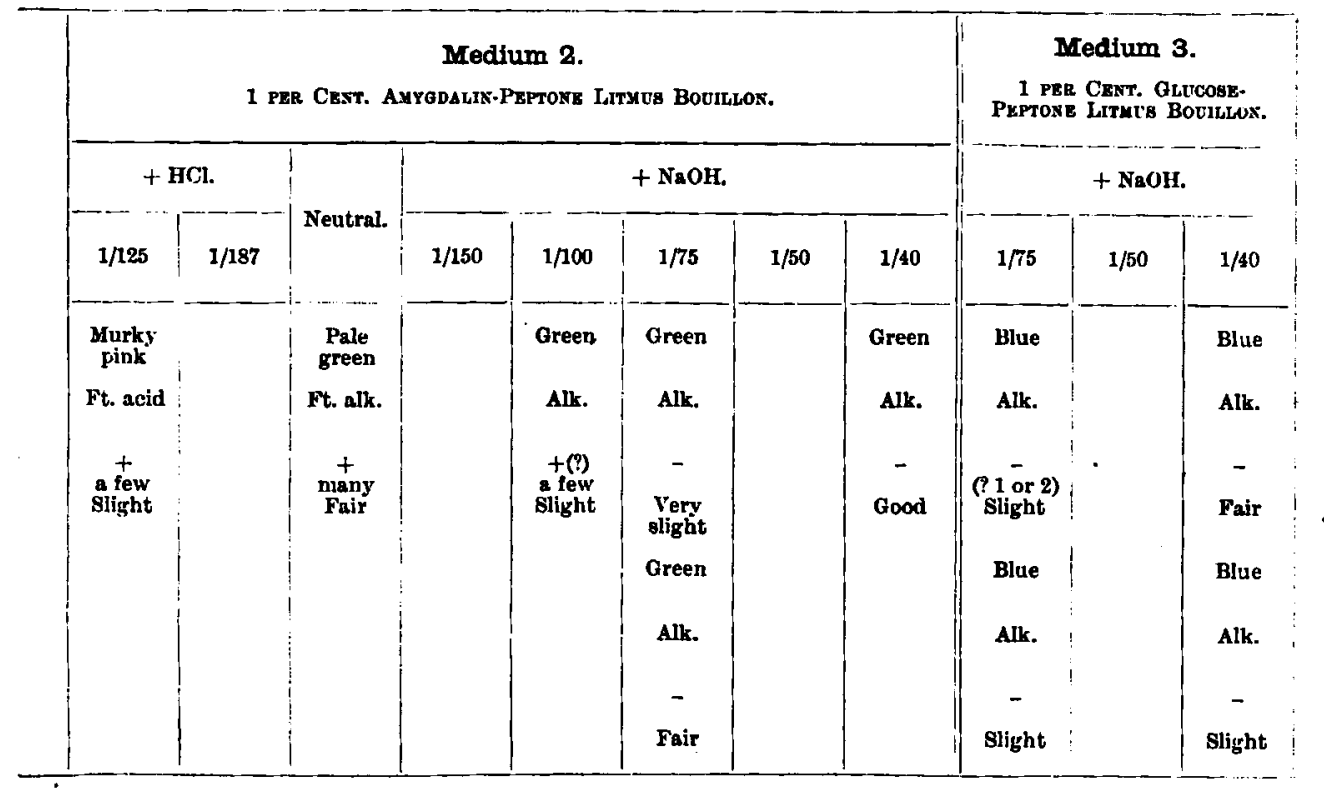

variable in extent as in the earlier experiments, but growth was maintained in the presence of sodium chloride varying from 0.5 per cent. to 5 per cent. in the acid, neutral, and alkaline media. In the weak acid tubes the best results were obtained in media without sodium chloride, and in that containing 0.5 per cent.

A slight change in reaction of the media was noticeable in the cultures of both strains, the weak acid media frequently becoming slightly alkaline or neutral, and the neutral medium slightly alkaline. The change in reaction occurred with greater frequency with strain H.O. than with N.M.

Growth was not vigorous in any of the anygdalin and salt series, but occurred in the acid and alkaline media of both the control series and of those series in which the sodium chloride content varied from 0.5 per cent. to 6 per cent. Growth also occurred in the few examples of neutral media included in the control series and in the 1.0 per cent. and 3 per cent. $\mathrm{NaCl}$ series of strain N.M.

In the glucose and salt series, which consisted only of a few examples of alkaline media, the most uniform growth was obtained in media containing 1 per cent. $\mathrm{NaCl}$ and of alkalinity $\mathrm{N} / 75$ and $\mathrm{N} / 50$. Good growth was also obtained in N/50 of the control series of H.O. and in N/75 and N/50 of this and of the 0.5 per cent. $\mathrm{NaCl}$ series of N.M. With tonicity higher than 1 per cent. growth was very slight, and insufficient to cause change of colour byacid production.

The foregoing remarks apply to both strains unless otherwise stated. Further details concerning the behaviour of each strain in the various media will be found in the tables. (Table III.)

\section{INvolution FoRMs.}

Involution forms were very prevalent, and were found with the typical bacilli both in the sugar-free peptone bouillon and in the various carbon compound media. Although associated with typical 
bacilli in the presence of each one of the carbon compounds used, they were particularly noticeable, in both strains, in media containing raffinose, lactose, isodulcite, and amygdalin. They were present in great diversity of form, such as longer and more slender rods than normal, short rods, rods with swollen or club-shaped ends, in vacuolated form, and as long threads. In several instances a very small cocco-bacillus-like form was also met with, notably with strain H.O. in some of the examples of the media containing amygdalin, inulin, raffinose, mannite, isodulcite, or arabinose; and similarly with N.M. in inulin and mannite media. This form was also found in both strains in some of the sugar-free media. The majority of these forms resemble those mentioned by Welch and Nuttall (18924) as occurring in their old cultures in 5 per cent. or 10 per cent. sugar gelatin or agar, as the case may be; but they were only present to a minor degree in sugar bouillon as used by them.

The typical form of both strains was mainly adhered to in the acid media of all the different series, except in the series containing lactose, in which greater diversity of form existed. Media of neutral reaction or alkaline to degree $N / 200$ to $N / 50$ were the most favourable media for the production of these different forms, and in the neutral media particularly great variability was observed. Thread forms were frequently found in media of a high degree of alkalinity, but occurred also in others. Both generally and specifically, the involution forms were more prevalent in strain H.O. than in strain N.M., with the exception of the thread form, which was more frequently found in cultures of strain N.M. The short forms in both strains were more prevalent in the presence of the alcohols, and occurred with least frequency in the presence of the dioses; and in the media containing the latter compounds the cocco-bacillary form was absent. The vacuolated forms were present, to a marked degree, in both strains, in the presence of maltose. Media containing arabinose furnished the fewest instances of the occurrence of involution forms.

\section{SUMMARY.}

The results obtained in the foregoing experiments may be summarised as follows:-

1. Spore formation may be induced in the $B$. aerogenes capsulatics group by the addition of certain carbon compounds to peptone bouillon media in proportion of 1 per cent., while the addition of others favours growth, but not sporulation.

2. The carbon compounds found capable of inducing sporulation were :-

Arabinose, raffinose, inulin, mannite, dulcite, isodulcite, and amygdalin; and of these mannite and amygdalin appear to give the best results. 
3. The non-occurrence of sporulation was associated with the presence of $d$-glucose, saccharose, maltose, and lactose; these sugars were readily acted upon by the bacilli of each strain with the production of acid.

4. The presence of acid, either as a primary constituent of the medium, or as the resultant of bacterial action upon the sugar contained in the same, appears to have an inhibitory effect upon sporulation, but this effect is not absolute, since spores were occasionally met with in the media containing $\mathrm{HCl}$, and in one instance were also found in the presence of formed acid due to action upon raffinose by strain N.M.

It therefore appears probable that acid is only one of many inhibitory factors.

5. Alkaline media are more conducive to sporulation than either acid or neutral media, and appear to be necessary for its occurrence in any high degree.

With the strains investigated, the optimum degree of alkalinity appeared to lie between $\mathrm{N} / 200-\mathrm{N} / 50$, the media of degrees alkalinity $\mathrm{N} / 100, \mathrm{~N} / 75, \mathrm{~N} / 50$ being especially favourable.

6. Sodium chloride does not appear to be a factor influencing sporulation, since its presence in percentage value varying from 0.5 to 5 neither increased nor inhibited the spore formation in those media already found suitable for the occurrence, and from which, in the first instance, sodium chloride had been omitted. Neither did the addition of sodium chloride induce sporulation in the media found to be unfavourable from causes apart from absence of salt.

7. Sporulation will sometimes occur in sugar-free bouillon.

8. In the presence of a carbon compound favourable to sporulation, one strain will show greater readiness to sporulate than another, a fact borne out in the present series of experiments by the denaturised Rauschbrand strain N.M. showing a greater disposition to sporulate than the typical $B$. aerogenes capsulatus strain H.O.

The results obtained are in close agreement with those recorded by Dr. Noguchi, who added the same carbon compounds, with the exception of isodulcite, in similar proportions to both sugar-free bouillon and Hiss's serum water. In addition, he employed sorbite (Hiss's serum water) for the induction of sporulation, with positive results; and lævulose, glycogen, and dextrin, with negative results. He also observed the occasional occurrence of sporulation in sugar-free bouillon, as well as the variation in capacity to produce spores exhibited by different strains in media containing carbon compounds favourable to sporulation.

In conclusion, I desire to express my thanks to Dr. Noguchi for his direction and help. 


\section{REFERENCES.}

1. Noevchi, H. . . . . Proc. Nero York Path. Soc., 1907-8, N.S., vol. vii. p. 196.

2. Dunham, E. K. . . . . Johns Hopkins Hosp. Bull., Baltimore, 1897, vol. viii. p. 68 .

3. WrLCH . . . . . . See note in Dunham's paper, ibid.

4. Wrich, William, aNd Johns Hopkins Hosp. Bull., Baltimore, 1892, Grorge Nutrall vol. iii. p. 81 .

5. Hzrtir, C. . . . . . Journ. Biolog. Chem., New York, 1906, vol.

6. Fratenkel, E. . . . . “Ueber Gas Phlegmonen," Hamburg and Leipzig, 1893.

7. Hitschmann, F., und Ahad.Sitzungsb. d. Kais. Wissensch. in Wien, O. Lindenthal $\quad 1899$, Bd. cviii. Abthiel. 3, S. 67.

8. Schattrenfoo, F., uxd Arch. f. Hyg., München u. Leipzig, 1900, Bd R. Grassberoer xxxvii. S. 54.

9.

,

, .

Centralbl. f. Bakteriol. u. Parasitenk., Jena, 1899, Abth. 2, Bd. v. S. 697.

10. JACQUE, L. . . . . . Tbid., Jena, 1904, Abth. 1, Orig. Bd. xxxvi.

11. SkLter S. 28.

Ibid., Jena, 1904, Abth. 1, Orig. Bd. xxxvii. S. 381 . 